\title{
EVALUASI MANAJEMEN RISIKO TEKNOLOGI INFORMASI PADA PERUSAHAAN DAERAH AIR MINUM KOTA SALATIGA MENGGUNAKAN FRAMEWORK COBIT 5.0
}

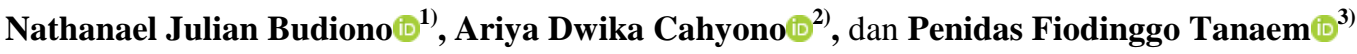 \\ ${ }^{1,2,3}$ Sistem Informasi Fakultas Teknologi Informasi Universitas Kristen Satya Wacana \\ 1,2,3 J1. Dr. O. Notohamidjojo No. 1 - 10, Blotongan, Kec. Sidorejo, Kota Salatiga, Jawa Tengah 50715 \\ E-mail :682016027@student.uksw.edu ${ }^{1)}$, ariyadc@uksw.edu ${ }^{2)}$, penidas.fiodinggo@uksw.edu ${ }^{3)}$.
}

\begin{abstract}
ABSTRAK
Pada Perusahaan Daerah Air Minum Kota Salatiga sudah menerapkan dan menggunakan teknologi informasi dalam menjalankan sebuah proses bisnis untuk mencapai tujuan perusahaan, dalam penggunaan teknologi infomasi dapat menambah nilai efektifitas dan efisiensi untuk mencapai tujuan organisasi, namun di sisi lain teknologi informasi juga mempunyai risiko yang dapat menyebabkan kerugian pada perusahaan dan tidak tercapainya sebuah tujuan perusahaan, Maka dari itu diperlukan sebuah penilaian terhadap pengelolaan sebuah manajemen risiko teknologi informasi. Analisis manajemen risiko teknologi informasi pada penelitian ini menggunakan framework COBIT 5.0 yang berfokus pada subdomain EDM03 dan APO12 dan menghasilkan sebuah nilai capability level untuk subdomain EDM03 berada pada level 4 (Predictable Process) dan untuk subdomain APO12 berada pada level 3 (Established Process) untuk nilai Capability level saat ini dengan nilai Capability Level yang ingin dicapai pada subdomain EDM03 dan APO12 memiliki $G A P$ yang berbeda beda. Selanjutnya juga diperlukan identifikasi risiko untuk mengetahui apakah untuk saat ini risiko yang dapat terjadi sudah dikontrol dan dapat menurunkan dampak dan kemungkinan kerugian dari risiko tersebut dengan melakukan penilaian risiko (Risk Assessment). Setelah menentukan nilai capability level dan risk assessment maka dari hasil yang diperoleh disusun rekomendasi bagi Perusahaan Daerah Air Minum Kota Salatiga agar mencapai level yang diinginkan oleh Perusahaan Daerah Air Minum Kota Salatiga yaitu level 5 (Optimizing Process) sehingga teknologi informasi dapat lebih mendukung organisasi dalam mencapai tujuan
\end{abstract}

Kata Kunci : COBIT 5, Manajemen Risiko, Teknologi Informasi, Analisis Gap, Level Kapabilitas.

\section{PENDAHULUAN}

Risiko TI merupakan risiko pada organisasi yang disebabkan oleh penggunaan TI dalam suatu organisasi, terdiri dari semua kejadian yang terkait dengan penggunaan TI dan memiliki potensi yang berdampak pada organisasi.(ISACA, 2012) Adapun pengertian manajemen risiko TI menurut (Blockdijk, dkk, 2008) adalah suatu upaya dari perencanaan, pengorganisasian memimpin dan kegiatan untuk meminimalkan dampak dari kerugian akibat kecelakaan pada biaya yang paling dapat diterima. Untuk memenuhi kebutuhan spesifik organisasi keberhasilan manajemen risiko harus menyeimbangkan pengendalian risiko dan teknik risiko pembiayaan dengan mempertimbangkan visi, misi, nilai - nilai dan tujuan organisasi. (Blokdijk, 2008) selain itu adapun beberapa faktor yang dapat mendukung sebuah proses manajemen risiko TI yaitu dari manajer TI perusahaan itu sendiri. Manajemen risiko merupakan proses yang memungkinkan manajer TI untuk menyeimbangkan biaya operasional dan biaya ekonomi untuk tindakan pengamanan dalam upaya melindungi sistem IT dan data yang mendukung misi organisasi. (Stoneburner dkk, 2012 Risiko dapat dihadapi dengan membuat sebuah manajemen risiko yang baik sehingga dapat memberikan pertimbangan kepada perusahaan secara terstruktur dengan memperhatikan segala bentuk ketidak pastikan dalam pengambilan keputusan dan tindakan yang harus diambil untuk menangani risiko tersebut. (Robert \& Moeller, 2011) maka dari itu pentingnya sebuah perusahaan untuk melakukan sebuah evaluasi manajemen risiko agar pengelolaan risiko dalam perusahaan dapat terlaksana dengan baik sehingga dapat mengurangi dampak negatif dari risiko perusahaan.

Perusahaan Daerah Air Minum Kota Salatiga sebagai Badan Usaha Milik Daerah (BUMD) sudah dirintis oleh Pemerintah Belanda sejak tahun 1921. Pada tahun 1968 Surat Keputusan Walikota madya Kepala Daerah Tingkat II Salatiga Nomor : 44/Kepda/Um-Pan tanggal 30 Desember 1967 dan Surat Keputusan Dewan Perwakilan Rakyat Daerah Gotong Royong (DPRD GR) Nomor : 8/DPRD-GR/Um-Pan tanggal 18 Mei 1968("PDAM Kota Salatiga" 2015), penyediaan air minum dikelola oleh Dinas Air Minum. Perusahaan Daerah Air Minum Kota Salatiga adalah sebuah perusahaan milik daerah yang bergerak di bidang penyediaan air minum untuk Kota Salatiga untuk saat ini PDAM kota Salatiga sudah menggunakan sistem informasi dan teknologi informasi yang berarti sudah tidak menggunakan sistem manual PDAM kota Salatiga memiliki sistem antara lain RO (Rekening Online), GIS 
(Geographic Information System), SIA (Sistem Informasi Akuntansi), BM (Baca Meter) meskipun begitu SI/TI yang ada di PDAM Salatiga belum terlaksana secara maksimal, SI/TI yang belum terlaksana secara maksimal tentunya akan menimbulkan sebuah risiko yang akan mengganggu untuk tercapainya sebuah tujuan proses bisnis di PDAM Kota Salatiga.

Adapun penelitian-penelitian terdahulu yang relevan dengan penelitian Evaluasi Manajemen Risiko Teknologi Informasi Menggunakan COBIT 5 IT Risk (Studi Kasus : PT. Petrokimia Gresik) oleh Nurfitri dan Suprapto. Pada penelitian ini Proses evaluasi penerapan teknologi informasi pada PT. Petrokimia Gresik, maka dapat didapatkan nilai Capability level pada subdomain EDM 03 berada pada level 2 sedangkan APO 12 berada pada level 3.(Firdaus, 2018).

Penelitian yang berhubungan selanjutnya adalah Evaluasi Manajemen Risiko Teknologi Informasi Menggunakan Framework COBIT 5 (Studi Kasus : PT. Kimia Farma (Persero) Tbk - Plant Watudakon) oleh Novia Dwi Setyaningrum dkk. Pada penelitian ini menghasilkan hasil dari capability level pada COBIT 5 untuk manajemen risiko yaitu EDM03 (Ensure Risk Optimation) dan APO12(Managed Risk). Domain EDM03 berada pada level 2 dan untuk APO12 berada pada level 1.(Setyaningrum, Suprapto, and Kusyanti 2018).

Penelitian tentang Evaluasi Manajemen Risiko Teknologi Informasi Menggunakan Kerangka Kerja COBIT 5 (Studi Kasus Pada Perum Jasa Tirta I Malang) oleh M. Habibullah Arief dan Suprapto penelitian ini menghasilkan Kemampuan Perum Jasa Tirta I Malang dalam menjalankan proses Ensure Risk Optimation (EDM03) dan Managed Risk (APO12) sama-sama berada pada level 2 yaitu Managed Process yang berarti aktivitas yang berkaitan dengan perencanaan, pemantauan (monitoring) dan penyesuaian pada proses Ensure Risk Optimation dan Managed Risk telah dikelola dengan baik oleh Perum Jasa Tirta I Malang serta hasil kerjanya telah ditetapkan, dipantau dan dikelola dengan tepat.(Arief \& Suprapto, 2018).

Penelitian tentang evaluasi manajemen risiko teknologi informasi menggunakan kerangka kerja COBIT 5.0 oleh (Megawati \& Syntia, 2018) dari Program Studi Sistem Informasi, Fakultas Sains dan Teknologi, UIN SUSKA Riau menghasilkan penerapan tingkat kapabilitas proses evaluasi, direct and monitor terkait penerapan sistem under web pada PT Pegadaian Kota Pekanbaru dengan hasil pencapaian yang diperoleh berada pada level 1 (Performed Process) dan persentase yang diraih yaitu $87.50 \%$.(Megawati \& Syntia, 2018).

Dalam uraian yang di jelaskan di atas, penulis melakukan sebuah penelitian terkait dengan manajemen risiko pada Perusahaan Daerah Air Minum Kota Salatiga. Sehingga dapat menghasilkan suatu saran dan rekomendasi yang dapat meminimalisir risiko. Untuk proses penilaian dan analisis menggunakan kerangka kerja COBIT 5 pada domain EDM03 (Ensure Risk optimization) dan APO12 (Manage Risk).

\section{RUANG LINGKUP}

Dalam penelitian permasalahan ini mencangkup sebagai berikut :

1. Cakupan permasalahannya adalah dalam penggunaan teknologi informasi pasti akan risiko yang dapat terjadi pada PDAM Kota Salatiga dan perlunya sebuah evaluasi manajemen risiko teknologi infomasi dalam pengelolaan risiko yang dapat terjadi.

2. Batasan penelitian ini adalah hanya fokus menganalisis manajemen risiko teknologi informasi menggunakan framework COBIT 5.0.

3. Hasil yang didapat dari penelitian ini dapat digunakan untuk pengukuran nilai kapabilitas dan rekomendasi pengelolaan manajemen risiko teknologi informasi sesuai dengan framework COBIT 5.0.

\section{BAHAN DAN METODE}

Berikut disajikan tentang dasar teori yang berkaitan tentang topik penelitian dan metode yang digunakan.

\subsection{Manajemen Risiko TI}

Risiko TI merupakan risiko yang di hasilkan dari penggunaan teknologi informasi, yang berpotensi menghasilkan umpan balik negatif. Adanya pengelolaan risiko TI tersebut dapat disebut manajemen risiko TI.

Manajemen risiko secara umum merupakan proses dengan tujuan untuk mendapatkan keseimbangan antara efisiensi dan merealisasikan peluang untuk mendapatkan keuntungan dan meminimalkan kerentanan dan kerugian. Manajemen risiko harus menjadi proses tanpa henti dan berulang yang terdiri dari beberapa fase, ketika diterapkan dengan benar, memungkinkan terjadinya perbaikan terus-menerus dalam pengambilan keputusan dan peningkatan kinerja. (Joint Task Force Transformation Initiative 2011)

Sebagaimana risiko TI merupakan risiko pada organisasi yang disebabkan oleh penggunaan TI dalam suatu organisasi, terdiri dari semua kejadian yang terkait dengan penggunaan TI dan memiliki potensi yang berdampak pada organisasi.(ISACA, 2014)

\subsection{COBIT 5.0}

COBIT 5 merupakan seperangkat pedoman dan hasil dokumentasi versi terbaru yang dihasilkan dan diterbitkan oleh ITGI (IT Governance Institute), yang berfungsi untuk membantu auditor, pemangku kepentingan atau pengguna (user) dalam menghubungkan antara model kendali bisnis dan model kendali TI.

COBIT 5 terbentuk dengan mengintegrasikan beberapa framework lain seperti Risk IT framework, VAL IT 2.0 dan COBIT 4.1. Selain itu COBIT 5 juga menyesuaikan antara best practices yang ada seperti ITIL V3, TOGAF dan standar relevan dari ISO.(ISACA \& Lainhart 2012) 
Menurut (ISACA, 2012) terdapat tujuh tahapan dalam siklus implementasi COBIT 5, yaitu:

1. Initiate Programme, merupakan tahap untuk mengidentifikasi penggerak perusahaan.

2. Define Problems and Opportunities, merupakan tahap untuk melakukan penilaian capability level untuk mengetahui kondisi organisasi saat ini dan menemukan kekurangan yang dimiliki.

3. Define Road Map, merupakan tahap untuk melakukan penetapan target dan analisis gap untuk meningkatkan upaya perbaikan dan mengidentifikasi adanya solusi potensial.

4. Plan Programme, merupakan tahap untuk merencanakan solusi yang dianggap tepat untuk diterapkan.

5. Execute Plan, merupakan tahap untuk mengimplementasikan solusi yang telah direncanakan serta melakukan pemantauan terhadap keselarasan bisnis.

6. Realized Benefits, merupakan tahap transisi secara berkelanjutan dengan menerapkan praktik tata kelola atau manajemen yang telah ditingkatkan kedalam proses bisnis dan memantau perkembangannya dengan memetakan pada matriks berdasarkan kinerja dan manfaat yang ingin diperoleh.

7. Review Effectiveness, merupakan tahap untuk melakukan evaluasi keberhasilan yang telah dicapai, kemudian melakukan identifikasi seluruh kebutuhan perbaikan secara berkala.(ISACA \& Lainhart, 2012)

Menurut (ISACA, 2012), COBIT 5 telah menyediakan dua subdomain proses yang berkaitan dengan penerapan manajemen risiko, antara lain:

1. EDM03 (Ensure Risk optimization)

Dalam proses ini berisi tentang pemahaman, artikulasi, dan komunikasi perusahaan dalam memastikan tingkatan risiko dan besarnya toleransi yang dapat di terima perusahaan, serta memastikan apakah risiko - risiko yang terkait dengan Teknologi Informasi telah diidentifikasi dan di kelola dengan baik. Dalam domain EDM03 memiliki 3 bagian domain atau subdomain proses yaitu :

1) EDM03.01 Evaluate Risk Management

2) EDM03.02 Direct Risk Management

3) EMD03.03 Monitor Risk Management

2. APO12 (Managed Risk)

Dalam proses ini berisi tentang bagaimana identifikasi yang di lakukan, penilaian dan pengurangan risiko yang terkait dengan teknologi informasi sesuai dengan tingkat toleransi yang telah di tentukan oleh manajemen eksekutif perusahaan. APO12 juga bertujuan untuk mengintegrasikan manajemen risiko teknologi informasi dengan manajemen risiko perusahaan (ERM). Domain APO12 memiliki 6 subdomain yaitu :
1) APO12.01 Collect Data
2) APO12.02 Analyze Risk
3) APO12.03 Maintain A Risk Profile
4) APO12.04 Articulate Risk

5) APO12.05 Define A Risk Management Action Portfolio

6) APO12.06 Respons To Risk

Dari domain tersebut akan dilakukan penilaian Capability Level untuk setiap proses tersebut digolongkan menjadi enam tingkatan, yaitu Level 0 (Incomplete Process), Level 1 (Performed Process), Level 2 (Managed process), Level 3 (Established Process), Level 4 (Predictable process) dan Level 5 (Optimized process).(ISACA \& Lainhart, 2012)

\subsection{Risk Assessment}

Risk Assessment merupakan proses keseluruhan dari Risk analysis dan risk evaluation. Risk Analysis adalah proses sistematis dalam menggunakan informasi yang ada untuk menentukan seberapa sering risiko dapat terjadi dan seberapa besar dampak yang dihasilkan bila risiko tersebut terjadi. (Cooper, dkk, 2004) Proses penilaian risiko pada risk analysis dapat dilakukan dengan metode seperti; bow-tie analysis, qualitative analysis, dan semi quantitative analysis. Sedangkan risk evaluation adalah proses dalam membandingkan risiko yang telah diperkirakan dengan kriteria risiko yang telah ditentukan. (Cooper,dkk, 2004)

\subsection{Metode Penelitian}

Ada beberapa langkah yang akan dilakukan dalam penelitian ini, langkah tersebut digambarkan pada Gambar 1.

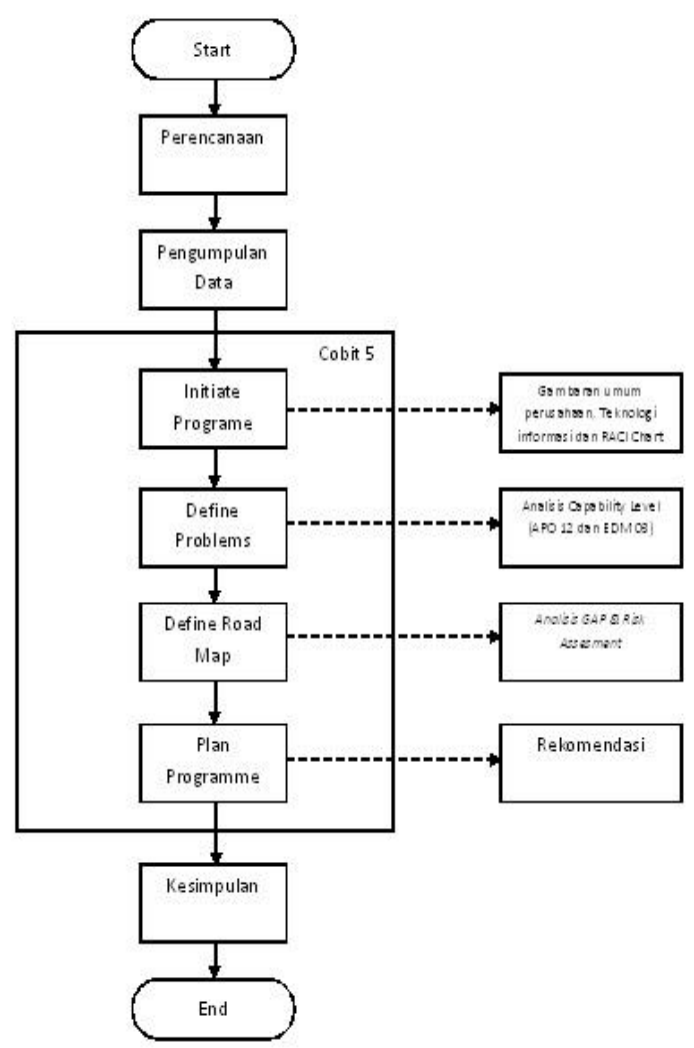

Gambar 1. Alur Penelitian 
1. Menentukan objek penelitian dan kerangka kerja yang tepat serta menggali informasi yang terkait.

2. Melakukan pengumpulan data, baik data primer maupun data sekunder dengan cara melakukan pengisian lembar kerja evaluasi, melakukan observasi langsung, melakukan wawancara dengan pihak pihak yang berwewenang dan studi kepustakaan.

3. Mendeskripsikan kondisi umum organisasi yang meliputi tujuan organisasi, penerapan teknologi informasi dan pihak - pihak yang bertanggung jawab berdasarkan RACI Chart.

4. Melakukan analisis penilaian Capability Level berdasarkan kerangka kerja COBIT 5 khususnya domain proses EDM 03 (Ensure Risk optimization) dan APO 12 (Manage Risk.)

5. Melakukan gap analysis risk assessment untuk setiap risiko yang melebihi batas toleransi organisasi.

6. Membuat rekomendasi yang berisi solusi potensial dengan tujuan untuk meningkatkan nilai kapabilitas organisasi.

7. Menyusun kesimpulan yang berisi ringkasan tentang semua langkah yang telah dilalui dalam proses penelitian guna menjawab rumusan masalah dan tujuan dari penelitian.

\section{PEMBAHASAN}

Pembahasan dalam penelitian ini adalah proses analisis manajemen risiko teknologi informasi menggunakan framework COBIT 5.0.

\subsection{Hasil Observasi dan Wawancara}

Observasi dilakukan untuk melengkapi kebutuhan informasi yang dibutuhkan untuk subdomain EDM03 (Ensure Risk optimization) dan APO12 (Manage Risk) untuk evaluasi manajemen risiko sistem pada Perusahaan Daerah Air Minum Kota Salatiga. Untuk menghasilkan observasi yang baik maka di lakukan pengamatan terhadap proses bisnis yang ada dan masalah - masalah yang ada pada perusahaan tersebut. Dari hasil observasi yang dilakukan menunjukkan bahwa pada Perusahaan Daerah Air Minum Kota Salatiga di dapatkan PDAM kota Salatiga belum mempunyai dokumen tersendiri untuk manajemen risiko TI. Untuk dokumen risiko TI masih belum tersedia secara lengkap dan detail karena PDAM kota Salatiga belum memiliki tim untuk pengelolaan risiko teknologi informasi secara spesifik sehingga belum bisa untuk melakukan pengelolaan dokumen risiko TI secara baik.

Kemudian wawancara dilakukan sebelum memberikan kuesioner dan setelah mendapatkan kuesioner kembali dari responden. Wawancara di lakukan dengan kepala bagian TI dan kepala bagian umum PDAM kota Salatiga. Hasil wawancara di dapatkan beberapa informasi yang dapat di jadikan sebuah parameter pengukuran untuk keselarasan antara hasil kuesioner dan hasil wawancara. Hasil wawancara yang didapatkan bahwa PDAM kota Salatiga memiliki sistem antara lain RO (Rekening Online), GIS (Geographic Information System), SIA (Sistem Informasi Akuntansi), BM (Baca Meter). Sistem ini di kendalikan oleh divisi TI dan pemantau jika terjadi sebuah kesalahan. Akan Tetapi belum ada bagian tim pengelolaan risiko TI yang terbentuk secara spesifik yang dapat mengendalikan risiko dan dokumen untuk mengendalikan risiko sebuah perusahaan. Dalam pengendalian risiko PDAM kota Salatiga sudah menerapkan manajemen pengendalian risiko untuk memonitor jika terjadi sebuah masalah. Hal ini akan di tindak lanjut oleh PIC yang sesuai dengan masingmasing kesalahan terjadi pada departemen tersebut.

Dalam mengukur tingkat kematangan penerapan teknologi di PDAM Kota Salatiga berdasarkan penyebar kuesioner dan wawancara di PDAM, Tahap pertama yang dilakukan adalah menentukan tujuan bisnis dari PDAM berdasarkan Visi Misi dan selanjutnya akan memetakan tujuan IT dari PDAM sesuai dengan COBIT 5 menggunakan Dimensi Balance Scorcard (BSC). Visi yang ada di PDAM Salatiga adalah: "Menjadikan perusahaan yang Maju, Mandiri, dan Profesional" Untuk mewujudkan visi tersebut maka dibentuk sebuah misi sebagai berikut:

1. Menyediakan air minum yang memenuhi standar kualitas, kuantitas dan kontinuitas.

2. Meningkatkan kemampuan sumber daya manusia menjadi pegawai yang memiliki etika, kinerja, dan profesional.

3. Meningkatkan pelayanan yang terjangkau dan memberikan kepuasan pelanggan.

4. Meningkatkan cakupan pelayanan yang terjangkau dan memberikan kepuasan pelanggan.

5. Mengelola sumber daya perusahaan yang profesional sehingga mampu memberikan pelayanan terbaik, meningkatkan kesejahteraan masyarakat dan meningkatkan kontribusi bagi PAD.

6. Menjaga hubungan harmonis dan peran yang seimbang dengan stakeholder dalam peningkatan pelayanan kepada pelanggan.

Dari point visi misi diatas maka diambillah misi poin keempat yaitu "Meningkatkan cakupan pelayanan yang terjangkau dan memberikan kepuasan pelanggan" karena sesuai dengan IT goal yang ingin dicapai oleh PDAM Salatiga. Proses pemetaan dilakukan dengan menggunakan tabel Enterprise Goals dan IT-Related Goals. Langkah pertama mencocokkan tujuan dari PDAM Salatiga dengan Enterprise goals seperti pada tabel 1. 
Tabel 1. Pemetaan tujuan bisnis PDAM Kota Salatiga ke dalam Enterprise Goals

\begin{tabular}{|l|l|l|l|l|}
\hline $\begin{array}{l}\text { Tujuan } \\
\text { Bisnis }\end{array}$ & No & $\begin{array}{l}\text { Tujuan } \\
\text { Enterprise }\end{array}$ & $\begin{array}{l}\text { BSC } \\
\text { Dimension }\end{array}$ & $\begin{array}{l}\text { Relation } \\
\text { ship }\end{array}$ \\
\hline $\begin{array}{l}\text { Meningkatk } \\
\text { an cakupan } \\
\text { pelayanan } \\
\text { yang } \\
\text { terjangkau }\end{array}$ & 10 & $\begin{array}{l}\text { Optimizati } \\
\text { on of } \\
\text { service } \\
\text { dan } \\
\text { melivery } \\
\text { coast. } \\
\text { kepuasan } \\
\text { pelanggan }\end{array}$ & & Primary \\
& & & & \\
& & & \\
\hline
\end{tabular}

Setelah dilakukan pemetaan tujuan bisnis ke dalam Enterprise Goals yang dimana terdapat satu tujuan enterprise yaitu optimization of service delivery coast. maka selanjutnya dapat ditentukan tujuan IT yang akan dicapai seperti pada Tabel 2.

Tabel 2. Pemetaan Enterprise Goals ke dalam ITGoals

\begin{tabular}{|l|l|l|l|l|}
\hline $\begin{array}{l}\text { Enterprise } \\
\text { Goals }\end{array}$ & No & IT Goals & $\begin{array}{l}\text { BSC } \\
\text { Dimension }\end{array}$ & Relationship \\
\hline $\begin{array}{l}\text { Optimization } \\
\text { of service } \\
\text { delivery } \\
\text { coast. }\end{array}$ & 4 & $\begin{array}{l}\text { Managed } \\
\text { IT- } \\
\text { Related } \\
\text { business } \\
\text { risk }\end{array}$ & Financial & Primary \\
& & \\
\hline
\end{tabular}

Setelah dilakukan pemetaan dari tujuan enterprise ke dalam tujuan IT maka diambil satu tujuan IT pada setiap tujuan enterprise yang nantinya akan digunakan untuk menentukan domain yang akan diambil sebagai dasar untuk menilai penerapan IT yang sudah dilakukan di PDAM Salatiga, dan domain yang akan digunakan dalam menilai akan dipetakan dari tujuan IT tersebut seperti pada tabel 3 .

Tabel 3. Pemetaan IT-Goals ke dalam Domain dan Sub Domain

\begin{tabular}{|l|l|l|l|}
\hline IT Goals & Domain & $\begin{array}{l}\text { Sub } \\
\text { Domain }\end{array}$ & Aktivitas \\
\hline $\begin{array}{l}\text { Managed } \\
\begin{array}{l}\text { IT-Related } \\
\text { business } \\
\text { risk }\end{array}\end{array}$ & EDM & EDM03 & $\begin{array}{l}\text { Memastikan tingkat } \\
\text { risiko... } \\
\text { penjelasannya diatas }\end{array}$ \\
\cline { 2 - 4 } & APO & APO12 & $\begin{array}{l}\text { Penilaian dan } \\
\text { pengurangan risiko }\end{array}$ \\
\hline
\end{tabular}

\subsection{RACI Chart}

Dalam mendapat informasi yang di butuhkan, penulis menyebarkan kuesioner kepada bagian yang memiliki hubungan antara Kepala bagian, Staf, PIC, Koordinator, User IT dalam penelitian ini di dasarkan pada pemetaan RACI Chart. Dalam pemetaan RACI Chart berbeda beda di sesuaikan dengan subdomain atau aktivitas yang berlaku agar didapatkan evaluasi setiap aktivitas yang ada. Pembagian RACI dibagi seperti berikut:
1. $\mathrm{R}$ (Responsible) adalah pihak atau bagian yang menjalankan proses,

2. A (Accountable) adalah pihak atau bagian yang bertanggung jawab pada proses,

3. C (Consulted) adalah pihak yang memberikan masukan terhadap proses yang ada,

4. I (Informed) adalah pihak yang mendapatkan informasi tersebut(ISACA, 2012).

Penelitian ini terhadap pada RACI Chart berdasarkan kepada tanggungjawab terhadap proses tersebut dalam mengelola atau menggunakan Teknologi Informasi yang ada di Perusahaan Daerah Air Minum Kota Salatiga. Pada tabel 4 adalah hasil tabel RACI Chart pada PDAM Kota Salatiga

Tabel 4. Tabel RACI

\begin{tabular}{|c|c|c|c|c|}
\hline \multirow{2}{*}{ Ket. } & \multicolumn{4}{|c|}{ Project Team Members } \\
\hline & $\begin{array}{c}\text { Kepala } \\
\text { Departemen }\end{array}$ & Koordinator & User & IT \\
\hline \multicolumn{5}{|c|}{ APO12 } \\
\hline APO12.01 & $\mathrm{C}$ & $\mathrm{A}$ & $\mathrm{R}$ & I \\
\hline APO12.02 & $\mathrm{I}$ & $\mathrm{C}$ & $\mathrm{R}$ & $\mathrm{A}$ \\
\hline APO12.03 & A & I & $\mathrm{C}$ & $\mathrm{R}$ \\
\hline APO12.04 & A & $\mathrm{R}$ & $\mathrm{C}$ & I \\
\hline APO12.05 & $\mathrm{A}$ & $\mathrm{R}$ & $\mathrm{I}$ & $\mathrm{C}$ \\
\hline APO12.06 & A & $\mathrm{R}$ & $\mathrm{C}$ & $\mathrm{I}$ \\
\hline \multicolumn{5}{|c|}{ EDM03 } \\
\hline EDM03.01 & A & C & $\mathrm{R}$ & I \\
\hline EDM03.02 & $\mathrm{A}$ & $\mathrm{C}$ & $\mathrm{I}$ & $\mathrm{R}$ \\
\hline EDM03.03 & A & $\mathrm{R}$ & I & $\mathrm{C}$ \\
\hline
\end{tabular}

\subsection{Hasil Temuan}

Berdasarkan hasil observasi lapangan, lembar evaluasi dan wawancara dengan pihak departemen bagian TI dan departemen bagian umum pada perusahaan daerah air minum Kota Salatiga, didapatkan beberapa hasil temuan sebagai berikut :

1. Sudah ada penggunaan teknologi informasi dan layanan tata kelola pada PDAM Kota Salatiga namun belum ada nya tim TI secara khusus dan spesifik.

2. Sistem yang di gunakan PDAM Kota Salatiga belum dibuat oleh tim TI PDAM Kota Salatiga sendiri, melainkan sistem yang digunakan dibangun oleh pihak ketiga/vendor development.

3. Karena sumber daya manusia yang belum memadai untuk membangun sebuah sistem sendiri maka dari itu PDAM Kota Salatiga melakukan sebuah pengalihan risiko dalam pengembangan dan penggunaan sistem aplikasi yang dibuat oleh pihak ketiga/vendor development.

4. Pada saat ini Tim TI di PDAM Kota Salatiga berfungsi sebagai reporting maintenance sistem, pemeliharaan hardware, pendampingan penggunaan sistem kepada user.

5. Karena belum adanya tim TI secara khusus pada PDAM Kota Salatiga maka PDAM Kota Salatiga 
juga belum memiliki tim secara khusus untuk pengelolaan risiko TI

6. Pada PDAM Kota Salatiga untuk pengelolaan risiko yang dilakukan masih secara umum dan untuk bagian teknologi informasi belum dilakukan pengelolaan risiko secara menyeluruh.

\subsection{Capability Model}

Capability Model memiliki proses yang dinyatakan dalam bentuk atribut proses yang dikelompokkan ke dalam tingkatan yang ditentukan berdasarkan pencapaian atribut proses tertentu(Gondodiyoto and Sanyoto 2007). Berikut penjelasan tiap level-nya:

1. Level 0 Incomplete Process merupakan proses dalam tujuan prosesnya tidak terlaksana atau gagal mencapai tujuan prosesnya.

2. Level 1 Performed Process merupakan proses yang mengimplementasikan untuk mencapai tujuan prosesnya.

3. Level 2 Managed Process merupakan proses yang hasilnya ditetapkan, dikontrol dan juga diimplementasikan juga dikelola.

4. Level 3 Established Process merupakan proses adanya dokumentasi dan memiliki hasil yang dikomunikasikan (untuk efisiensi organisasi).

5. Level 4 Predictable Process merupakan proses yang dimonitor, kemudian diukur dan memprediksi untuk mencapai hasil.

6. Level 5 Optimizing Process merupakan proses yang nantinya akan relevan dengan tujuan bisnis yang akan datang sehingga dapat diprediksikan kemudian ditingkatkan untuk memenuhi tujuan bisnis.(IT governance Institute, 2007).

\subsection{Analisis Tingkat Kematangan}

Setelah melakukan wawancara dengan kepala bagian umum perusahaan daerah air minum kota Salatiga, untuk keadaan saat ini, sudah mencapai level 3 (Established Process). Sedangkan perusahaan menginginkan keadaan manajemen risiko yang relevan dengan tujuan bisnis yang akan datang sehingga dapat diprediksi kemudian ditingkatkan untuk memenuhi tujuan bisnis. Menggunakan manajemen risiko dan proses yang umum apabila diperlukan, dengan pemantauan risiko keseluruhan organisasi, pengukuran dan pelaporan. Yang dimana sama dengan capability model COBIT 5, level 5 (Optimizing Process).

Tingkat kematangan dilakukan untuk mengetahui proses penerapan teknologi informasi pada PDAM Kota Salatiga. Dalam mengukur tingkat kematangan dilakukan penyebaran kuesioner kepada karyawan PDAM Salatiga, Kepala Departemen dan PIC team IT yang bertanggung jawab pada sistem aplikasi yang di gunakan PDAM Kota Salatiga menggunakan rumus perhitungan(1).

Indeks kematangan atribut diperoleh dari perhitungan total pilihan jawaban kuesioner dan pembobotan pilihan jawaban kemudian dibagi dengan jumlah responden yang ada.
Indeks Kematangan Atribut $=\frac{\sum(\text { Total Jawaban } x \text { Bobot })}{\text { Jumlah Responden }}$

Indeks kematangan atau dapat disebut penilaian tingkat kematangan diperoleh dari perhitungan indeks kematangan atribut lalu dibagi dengan aktivitas atau pada subdomain yang sudah dipilih (2).

Indeks Kematangan $=\frac{\sum \text { Indeks Kematangan Atribut }}{\text { Aktivitas }}$

\subsection{Analisis Perhitungan GAP}

Setelah melakukan identifikasi proses bisnis dan melakukan penyebaran kuesioner kepada karyawan PDAM Kota Salatiga, didapatkan hasil seperti pada tabel 5.

Tabel 5. Tabel Perhitungan GAP

\begin{tabular}{|l|l|l|l|}
\hline Aktivitas & $\begin{array}{l}\text { Kondisi } \\
\text { Saat Ini }\end{array}$ & $\begin{array}{l}\text { Yang } \\
\text { Diharapkan }\end{array}$ & Kesenjangan \\
\hline APO 12.01 & 3,75 & 5,00 & 1,25 \\
\hline APO 12.02 & 3,00 & 5,00 & 2,00 \\
\hline APO 12.03 & 3,00 & 5,00 & 2,00 \\
\hline APO 12.04 & 2,75 & 5,00 & 2,25 \\
\hline APO 12.05 & 2,25 & 5,00 & 2,75 \\
\hline APO 12.06 & 2,75 & 5,00 & 2,25 \\
\hline EDM 03.01 & 4,00 & 5,00 & 1,00 \\
\hline EDM 03.02 & 3,75 & 5,00 & 1,25 \\
\hline EDM 03.03 & 3,75 & 5,00 & 1,25 \\
\hline
\end{tabular}

APO 12.01 (Collect Data) APO 12.01 adalah proses pengumpulan data atau dapat disebut sebagai proses dokumentasi manajemen risiko TI yang ada di dalam organisasi PDAM Kota Salatiga. Proses ini memiliki tujuan untuk mencari tahu kondisi saat ini dalam analisis manajemen risiko. Berdasarkan proses bisnis dalam PDAM Kota Salatiga dengan menggunakan sistem aplikasi RO (Rekening Online), GIS (Geographic Information System), SIA (Sistem Informasi Akuntansi), BM (Baca Meter). Keseluruhan setiap risiko TI yang terjadi belum semua dilakukan proses dokumentasi, hanya risiko tertentu saja yang dilakukan proses dokumentasi kepada tim TI. Hal ini di perkuat oleh hasil pengambilan data kuesioner mendapatkan nilai 3,75 bahwa sudah adanya proses dokumentasi risiko di PDAM Kota Salatiga namun belum dilakukan secara maksimal. Sehingga dapat diambil kesimpulan dalam proses collect data pada organisasi atau perusahaan ini memiliki sebuah proses dokumentasi risiko yang baik. Berdasar hasil wawancara dengan kepala bagian TI dan kepala bagian umum proses pendokumentasian manajemen risiko TI untuk saat ini masih dilakukan belum berdasar sistem atau masih di katakan masih secara manual dengan proses jika user TI ada kendala atau usulan pada sistem user TI masih melaporkan via email atau pada saat briefing atau rapat kepada bagian TI dan bagian TI akan menganalisa dan menyampaikan kepada kepala bagian TI dan kepada bagian vendor development sistem aplikasi, setelah ada perbaikan dari vendor developer bagian TI akan menyampaikan ke user TI. 
APO 12.02 (Analyze risk) APO 12.02 adalah sebuah proses analisis manajemen risiko TI yang ada di dalam organisasi PDAM Kota Salatiga. Proses analisis ini memiliki tujuan untuk melihat fungsi control yang dilakukan untuk mengurangi risiko TI. Dalam menjalankan proses bisnis yang ada pada PDAM Kota Salatiga menggunakan sistem aplikasi yang di bangun oleh pihak ketiga / vendor development untuk mengurangi risiko TI yang dapat terjadi karena PDAM Kota Salatiga untuk saat ini belum memiliki tim TI yang cukup spesifik dan khusus dalam hal membuat sebuah program, hal ini diperkuat oleh hasil pengambilan data kuesioner yang mendapatkan nilai 3,00 dalam analisis risiko di PDAM Kota Salatiga. Sehingga dapat disimpulkan dalam proses analyses risk, PDAM Kota Salatiga memiliki proses analyses risk atau fungsi kontrol risiko yang sudah cukup baik.

APO 12.03 (Maintain a risk profile) APO 12.03 adalah proses pemeliharaan profil risiko TI yang ada pada PDAM Kota Salatiga dengan adanya proses ini memiliki tujuan untuk mencari tahu kondisi PDAM Kota Salatiga saat ini dalam pemeliharaan profil risiko TI. Dalam menjalankan proses bisnis pada PDAM Kota Salatiga melakukan pemeliharaan profil risiko TI yang terjadi, dilakukannya perawatan infrastruktur dan sarana yang dimiliki saat ini untuk menopang pencapaian tujuan bisnis. Hal ini diperkuat pada pengambilan data kuesioner dengan mendapatkan nilai 3,00 dalam pemeliharaan profil risiko TI di PDAM Kota Salatiga. Sehingga dapat diambil sebuah kesimpulan dalam proses maintain a risk profile PDAM Kota Salatiga sudah cukup baik. Berdasarkan hasil wawancara kepada kepala bagian TI dan kepala bagian umum PDAM Kota Salatiga menjelaskan bahwa adanya perangkat dan infrastruktur yang baik sangat penting bagi kelangsungan proses bisnis yang ada saat ini sehingga dapat mencapai sebuah tujuan bisnis yang diharapkan, kepala bagian umum PDAM Kota Salatiga menjelaskan selain melakukan perawatan pada perangkat PC dilakukan juga maintenance dan update pada sistem yang ada saat ini beliau berkata "sistem pada PDAM Kota Salatiga memang belum dikatakan sempurna, namun dengan adanya sistem sudah sangat membantu proses bisnis di PDAM Kota Salatiga maka dari itu kita harus melakukan perawatan secara berkala."

APO 12.04 (Articulate risk) APO 12.04 adalah proses mengartikulasikan risiko TI yang ada pada PDAM Kota Salatiga. Pada proses ini memiliki tujuan untuk mencari tahu kondisi PDAM Kota Salatiga saat ini dalam mengartikulasikan risiko. Dalam menjalankan proses bisnis pada PDAM Kota Salatiga dalam mengartikulasikan risiko dilakukan proses pelaporan kepada bagian TI dan bagian lainnya yang terkena dampak dalam gangguan teknis. Hal ini di perkuat dengan pengambilan data kuesioner yang mendapatkan nilai 2,75. Maka dapat disimpulkan telah terjadinya proses artikulasi risiko pada PDAM Kota Salatiga dan dalam hal ini PDAM Kota Salatiga memiliki Articulate Risk yang cukup.

APO 12.05 (Defined a risk management action portfolio) APO 12.05 adalah proses menentukan portfolio manajemen risiko yang ada pada PDAM Kota Salatiga. Pada proses ini memiliki tujuan untuk mencari tahu kondisi saat ini dalam menentukan portfolio manajemen risiko di PDAM Kota Salatiga. Untuk menjalankan proses bisnis yang ada PDAM Kota Salatiga dalam meminimalisir risiko yang mungkin terjadi masih kurang dalam melakukan fungsi kontrol karena dalam PDAM Kota Salatiga belum adanya bagian khusus untuk mengatur dan mengelola manajemen risiko TI yang mungkin terjadi. Hal ini diperkuat oleh hasil pengambilan data kuesioner mendapatkan nilai sebesar 2,25. Maka dapat disimpulkan pada proses defined a risk management action portfolio pada PDAM Kota Salatiga sudah cukup.

APO 12.06 (Respond to risk) APO 12.06 adalah proses respon terhadap risiko yang ada pada PDAM Kota Salatiga. Proses ini memiliki tujuan untuk mencari tahu kondisi saat ini pada PDAM Kota Salatiga dalam merespons risiko yang dapat terjadi. Untuk menjalankan proses bisnis saat ini PDAM Kota Salatiga sudah melakukan upaya dalam respons terhadap risiko yang dapat terjadi tetapi masih dilakukan secara umum dan belum secara khusus merespons risiko yang dapat terjadi di dalam bagian TI. Dalam melakukan respons terhadap risiko setiap divisi akan berdiskusi via email, Whatsapp grup, briefing dan pada saat ada meeting. Hal ini diperkuat oleh hasil pengambilan data kuesioner yang mendapatkan nilai sebesar 2,75. Maka dapat disimpulkan PDAM Kota Salatiga dalam merespons sebuah risiko yang dapat terjadi sudah cukup.

EDM 03.01 (Evaluate Risk Management) EDM 03.01 adalah proses evaluasi manajemen risiko yang ada pada PDAM Kota Salatiga. Proses ini memiliki tujuan untuk mencari tahu kondisi saat ini pada PDAM Kota Salatiga dalam mengevaluasi manajemen risiko TI pada perusahaan. Untuk saat ini PDAM Kota Salatiga sudah mengetahui, memeriksa dan membuat penilaian tentang risiko yang terjadi terhadap penggunaan TI untuk saat ini dan untuk masa mendatang, namun PDAM Kota Salatiga belum melakukan implementasi menggunakan sebuah framework. Hal ini diperkuat oleh hasil pengambilan data kuesioner mendapatkan nilai sebesar 4,00. Maka dapat di ambil kesimpulan PDAM Kota Salatiga dalam melakukan sebuah evaluasi manajemen risiko TI sudah baik.

EDM 03.02 (Direct Risk Management) EDM 03.02 adalah proses arahan manajemen risiko yang ada pada PDAM Kota Salatiga. Proses ini memiliki tujuan untuk mencari tahu pada kondisi saat ini PDAM Kota Salatiga dalam mengarahkan manajemen risiko TI yang terjadi pada perusahaan untuk saat ini PDAM Kota Salatiga sudah melakukan sebuah arahan penerapan manajemen risiko TI untuk kepentingan keamanan TI sehingga risiko yang dapat terjadi tidak mengganggu proses bisnis dan 
tujuan bisnis pada PDAM Kota Salatiga. Hal ini diperkuat dengan hasil pengambilan data kuesioner yang mendapatkan nilai sebesar 3,75. Sehingga dapat diambil kesimpulan PDAM Kota Salatiga dalam melakukan Direct Risk Management sudah cukup baik. Berdasar hasil wawancara yang di dapat dari kepala bagian TI dalam upaya melakukan pengarahan manajemen risiko TI, PDAM Kota Salatiga sudah pernah melakukan pengarahan dan seminar kepada karyawan - karyawan tentang manajemen risiko TI dan risiko TI yang dapat terjadi pada perusahaan.

EDM 03.03 (Monitor Risk Management) EDM 03.03 adalah proses monitor manajemen risiko yang ada pada PDAM Kota Salatiga. Proses ini memiliki tujuan untuk mencari tahu kondisi saat ini PDAM Kota Salatiga dalam memonitor manajemen risiko yang dapat terjadi. Untuk saat ini PDAM Kota Salatiga melakukan monitor risiko
TI yang terjadi dengan menampung setiap kesalahan, usulan perbaikan pada setiap sistem lalu bagian TI akan berdiskusi dan mengidentifikasi masalah yang ada dan akan melakukan perbaikan dengan melibatkan sebuah vendor organisasi untuk melakukan sebuah perbaikan sistem. Hal ini diperkuat dengan hasil pengambilan data kuesioner yang mendapatkan nilai sebesar 3,75. Maka dapat disimpulkan PDAM Kota Salatiga dalam Monitor Risk Management sudah bisa dikatakan baik. Adapun hasil identifikasi risiko pada PDAM Kota Salatiga beserta dampak yang dilakukan sebagai risk assessment dapat dilihat pada tabel 6 .

Tabel 6. Tabel Risk Assessment

\begin{tabular}{|c|c|c|c|c|c|c|c|}
\hline \multirow{2}{*}{ Sumber Risiko } & \multirow{2}{*}{ Risiko } & \multicolumn{3}{|c|}{ Frekuensi kejadian } & \multicolumn{3}{|c|}{ Dampak } \\
\hline & & $\mathrm{S}$ & $\mathrm{K}$ & TP & B & $\mathrm{S}$ & $\mathrm{K}$ \\
\hline \multirow[t]{5}{*}{ Alam } & Gempa Bumi & & $\boldsymbol{V}$ & & & & $\boldsymbol{V}$ \\
\hline & Radiasi Panas & & & $\boldsymbol{V}$ & & & \\
\hline & Debu/Kotoran & & $\boldsymbol{V}$ & & & & $\checkmark$ \\
\hline & Kelembaban & & $\boldsymbol{V}$ & & & & $\checkmark$ \\
\hline & Kebakaran & & & $\checkmark$ & & & \\
\hline \multirow[t]{8}{*}{ Manusia } & Informasi diakses oleh pihak yang tidak berwenang & & & $\boldsymbol{V}$ & & & \\
\hline & Hilangnya Data & & & $\boldsymbol{V}$ & & & \\
\hline & Human error & & $\boldsymbol{V}$ & & & $\boldsymbol{V}$ & \\
\hline & Data dan informasi tidak sesuai fakta & & & $\checkmark$ & & & \\
\hline & Mantan karyawan user masih memiliki akses informasi & & & $\boldsymbol{V}$ & & & \\
\hline & Kebocoran informasi atau data & & & $\boldsymbol{V}$ & & & \\
\hline & Kerusakan akibat ulah manusia : cybercrime atau pembajakan & & & $\boldsymbol{V}$ & & & \\
\hline & Tidak mengganti user id & & & $\checkmark$ & & & \\
\hline \multirow{8}{*}{$\begin{array}{l}\text { Sistem dan } \\
\text { infrastruktur }\end{array}$} & Server down & & $\checkmark$ & & & 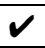 & \\
\hline & Koneksi jaringan terputus & & 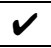 & & & $\checkmark$ & \\
\hline & Gagal update & & $\checkmark$ & & & $\checkmark$ & \\
\hline & Kerusakan hardware & & $\checkmark$ & & & $\checkmark$ & \\
\hline & Backup failure & & & $\boldsymbol{V}$ & & & \\
\hline & Terinfeksi virus & & & $\boldsymbol{V}$ & & & \\
\hline & Data corrupt & & & $\checkmark$ & & & \\
\hline & Kurang baiknya kualitas jaringan & & $\checkmark$ & & & $\checkmark$ & \\
\hline $\begin{array}{l}\text { Keterangan Frek Kej } \\
\text { TP : Tidak Pernah } \\
\text { K : Kadang } \\
\text { S : Sering }\end{array}$ & $\begin{array}{c}\text { Keterangan Dampak } \\
\text { K : Kecil } \\
\text { S : Sedang } \\
\text { B : Besar }\end{array}$ & & & & & & \\
\hline
\end{tabular}




\subsection{Rekomendasi}

Setelah dilakukan perhitungan kematangan dan kesenjangan maka penulis memberikan saran pada domain yang belum mencapai harapan kepada Perusahaan Daerah Air Minum Kota Salatiga sebagai berikut:

\section{EDM03}

Saran yang diberikan adalah adanya pelatihan yang rutin untuk ke depan dapat membentuk sebuah sumber daya manusia yang menunjang sehingga dapat membentuk sebuah tim TI sendiri sehingga ke depan PDAM Kota Salatiga dapat membangun sebuah sistem aplikasi sendiri dan akan terbentuknya sebuah tim pengelolaan risiko TI sehingga pengelolaan manajemen risiko TI akan terlaksana dan terkendali dengan baik.

2. $\mathrm{APO} 12$

Saran yang diberikan adalah perlunya sebuah perekrutan dan pembentukan tim TI secara khusus dan spesifik dengan sumber daya manusia yang menunjang sehingga dalam melakukan pekerjaan dan pelayanan pada PDAM Kota Salatiga yang menggunakan sistem aplikasi dapat terkendali dan mengurangi risiko yang dapat terjadi dan perlunya sebuah pembentukan sebuah tim pengelolaan manajemen risiko teknologi informasi sehingga dokumentasi profile risk dan respons terhadap risiko TI yang dapat terjadi pada PDAM Kota Salatiga dapat terlaksana dan terkendali dengan baik, dan perlunya di lakukan peremajaan pada hardware yang tersedia untuk menghindari terjadinya hal yang menghasilkan risiko teknologi informasi pada perusahaan dan tetap dilakukan maintenance pada sistem secara rutin berkala sehingga sistem yang digunakan dapat berkerja secara maksimal sesuai proses bisnis pada PDAM Kota Salatiga.

\section{KESIMPULAN}

Berdasarkan hasil analisis dan pembahasan dapat dilihat bahwa manajemen risiko teknologi informasi pada Perusahaan Air Minum Daerah Kota Salatiga dapat diperoleh kesimpulan sebagai berikut proses analisis manajemen risiko teknologi informasi pada PDAM Kota Salatiga menggunakan framework COBIT 5 khususnya subdomain APO 12 dan EDM 03 menghasilkan nilai capability level untuk subdomain APO12.01 (collect data) berada pada level 3 yaitu Established Process, APO 12.02 (analyses risk) berada pada level 3 yaitu Established Process, APO12.03 (maintain a risk profile) berada pada level 3 yaitu Established Process, APO12.04 (articulate risk) berada pada level 2 yaitu Managed Process, APO12.05 (defined a risk management action portfolio) berada pada level 2 yaitu Managed Process, APO12.06 (respons to risk) berada pada level 2 yaitu Managed Process. Sedangkan untuk nilai capability level subdomain EDM03.01 (evaluate risk management) berada pada level 4 yaitu Predictable Process, EDM03.02 (direct risk management) berada pada level 3 yaitu Established process, EDM 03.03 (monitor risk management) berada pada level 3 yaitu
Established Process. Nilai capability level saat ini dengan nilai capability level yang ingin dicapai pada subdomain APO12 dan EDM03 memiliki GAP yang berbeda-beda.

\section{SARAN}

Saran yang diberikan penulis bagi penelitian selanjutnya diperlukan penilaian khusus terhadap pembentukan tim TI secara khusus pada PDAM Kota Salatiga dan penilaian terhadap pembentukan tim manajemen risiko teknologi informasi dalam mengontrol dan mengelola risiko yang dapat terjadi di PDAM Kota Salatiga dan dengan adanya hasil penelitian ini dapat dikembangkan ke depannya. Sehingga adanya tim TI secara khusus dan tim pengelolaan risiko TI dapat mengelola risiko dalam PDAM Kota salatiga dengan baik dan kontrol risiko pada PDAM Kota Salatiga dapat dikendalikan dengan baik sehingga dapat mencapai tujuan bisnis yang ditentukan.

\section{DAFTAR PUSTAKA}

Arief, M. Habibullah, and Suprapto. 2018. "Evaluasi Manajemen Risiko Teknologi Informasi Menggunakan Kerangka Kerja COBIT 5 (Studi Kasus Pada Perum Jasa Tirta I Malang)." Jurnal Pengembangan Teknologi Informasi Dan Ilmu Komputer 2 (1): $101-10$. http://repository.ub.ac.id/1480/.

Blokdijk, G. (2008). IT Risk Management Guide-Risk Management Implementation Guide: Presentations, Blueprints, Templates; Complete Risk Management Toolkit Guide for Information Technology Processes and Systems: Presentations, Blueprints, Templates; Complete Risk Management Toolkit Guide for Information Technology Processes and Systems. Lulu. com

Dooper, S. G, and P.walker. 2004. Project Risk Management Guidelines: Managing Risk in Large Projects and Complex Procurements, Chichester, West Sussex. John wiley \& sons Ltd.

Firdaus, Nurfitri Zukhrufatul. 2018. "Evaluasi Manajemen Risiko Teknologi Informasi Menggunakan COBIT 5 IT Risk (Studi Kasus : PT . Petrokimia Gresik)" 2 (1): 91-100..

ISACA., and J W Lainhart. 2012. COBIT 5: A Business Framework for the Governance and Management of Enterprise IT COBIT 5. United States of America: ISACA. Vol. 34. http://tp.revistas.csic.es/index.php/tp/article/viewA rticle/432\%0Ahttp://files/399/432.html.

ISACA. 2012. COBIT 5: Enabling Processes. United States of America: ISACA.

IT governance Institute. 2007. COBIT 4.1:Framework, Control Objective, Management Guidelines, Maturity Models. United States of America: Rolling Meadow.

Megawati, Megawati, and Ana Syntia. 2018. "Evaluasi 
Manajemen Resiko Teknologi Informasi Menggunakan Kerangka Kerja Cobit 5.0.” Jurnal Ilmiah Rekayasa Dan Manajemen Sistem $\begin{array}{llll}\text { Informasi } & 4 & \text { (2): } & 118 .\end{array}$ https://doi.org/10.24014/rmsi.v4i2.5682.

"PDAM Kota Salatiga." 2015.2015. http://www.pdamsalatiga.com/info-perusahaan.

Robert, R., and Moeller. 2011. COSO Enterprise Risk Management: Establishing Effective Governance, Risk, and Compliance Processes. John wiley \& sons Ltd.

Setyaningrum, Novia Dwi, Suprapto, and Ari Kusyanti.
2018. "Evaluasi Manajemen Risiko Teknologi Informasi Menggunakan Framework COBIT 5 (Studi Kasus: PT . Kimia Farma (Persero) Tbk Plant Watudakon)." Jurnal Pengembangan Teknologi Informasi Dan Ilmu Komputer 2 (1): 143-52.

Stoneburner, G., Goguen, A., \& Feringa, A. (2002). Risk management guide for information technology systems. Nist special publication, 800(30), 80030.Gondodiyoto, and Sanyoto. 2007. Audit Sistem Informasi. Jakarta: Mitra Wacana Media. 